\title{
DOES SOCIAL ENTREPRENEURSHIP AFFECT TO ORGANIZATIONAL LEARNING AND BUSINESS PARTNERSHIP
}

\author{
Catur Susanto* \\ Student of Doctoral, Barawijaya University, Indonesia \\ Taher Alhabsji, Wilopo, Yusri Abdillah \\ Lecturer, Brawijaya University, Indonesia \\ *Corresponding Author Email: susantocatur790@gmail.com
}

\begin{abstract}
This paper targets at presenting examna affecting does social entrepreneurship organizational learning and business partnership with 168 respondent small medium entrepreneurs The sample of this study are 168 small scale business oriented apparel industry oriented creative industries in DKI Jakarta. The sampling technique is through the Slovin formula. Sources of data obtained through questionnaires and supported by field documentation. From the results of data acquisition, then analyzed through: (i) descriptive statistics; and (ii) inferential statistics through GSCA (Structured Generalized Component Analysis). The results of this study found that: (i) social entrepreneurship has a significant effect on organizational learning; (ii) social entrepreneurship has a significant effect on partnerships.
\end{abstract}

Keywords: Social Entrepreneurship, Organizational Learning, Partnership.

Cite this Article: Catur Susanto, Taher Alhabsji, Wilopo, Yusri Abdillah, Does Social Entrepreneurship Affect to Organizational Learning and Business Partnership, International Journal of Management (IJM), 11 (1), 2020, pp. 107-112. http://iaeme.com/Home/issue/IJM?Volume=11\&Issue $=1$

\section{INTRODUCTION}

SME has an important role for the economy, including: (i) as a support and driving force of the real sector; (ii) job creation; (ii) capital creator; (iii) contribute to exports; (iv) poverty reduction; and (v) able to reduce inequality between regions. However, MSMEs are also faced with various problems, such as high levels of competition and high risk of business failure. These problems are categorized as difficulties in governance, especially the weak nature of cooperation between SMEs. Various empirical studies prove that the main factors determining the success of MSME are determined by the application of strategic management, such as organizational learning, partnerships, competitive advantage, and business performance. Some of these aspects are categorized as forming aspects of social entrepreneurship entities 
(social entrepreneurship). However, there is still debate whether social entrepreneurship is truly able to be a determining factor for the success of MSMEs.

\section{LITERATURE REVIEW}

Understanding the effect of social entrepreneurship on organizational learning can be seen from the opinion expressed by Kirzner (1973) which states that entrepreneurs can see opportunities for entrepreneurial profit. Opportunities are considered imperfect market participants' knowledge, and they can be captured by anyone who discovers their whereabouts before others do. Thus, according to Kirzner, the opportunity requires differential access to existing information. By responding to this, people can obtain resources and put them back together to sell the results in the hope of making a profit (Shane, 2003).

Godói-de-Sousa and Júnior (2013) conducted a study on "Social Enterprises in Brazil: Socially Produced Knowledge Versus Social Innovation" which aims to investigate whether socially generated knowledge in social enterprises in Brazil has promoted social innovation and regional development. This research is exploratory and descriptive in nature, and was developed in two stages. Initially, the sample group consisted of 378 projects selected from the Solidarity Economic Enterprises mapping, conducted by the National Secretary for Solidarity Economics. The sample was surveyed to verify the main characteristics of the company. After that, interviews were conducted with key managers in a sample of 32 projects.

Research results show not easily propose a model or uniformity of action to disseminate learning in the context of third sector organizations which aims to social innovation. Each has its own logic and before carrying out the analysis, it is necessary to recognize the individuals who participate in it and their goals and thus understand the goals of the organization and the dynamics of learning.

\subsection{Proposition 1: Social Entrepreneurship Effect Organizational Learning Social Entrepreneurship and Business Partnership}

Brady and Haugh (2008) conducted research related to social entrepreneurship and business networks. Based on theoretical descriptive studies show that the structure of concepts, ties, content, context, and objectives identified from the theory can be applied to the analysis of social enterprise networks. This shows that social enterprises can encourage business partnerships. Through social enterprise partnerships will be stronger in the face of the fierce business competition.

Nelson and Jenkins (2006) tried to conduct research on potential partnerships between corporations and social entrepreneurs. The results of his research show that in periods of economic and political change and uncertainty, business budgets tend to be tight and community needs are high, there are greater incentives than before for companies, communities and public officials to work together to utilize social and commercial investment as effectively and efficiently as possible. Umi Karomah Yaumidin (2013) conducted a research on the challenges of multi-sector and multi-dimensional synergy between social entrepreneurship and corporate social responsibility. The results of his research show the distribution of corporate social responsibility programs based on social entrepreneurship triggers partnerships between companies and the community. The partnership built with the program is expected to be able to answer the challenges of multi-sector and multi-dimensional synergy between social entrepreneurship and social responsibility 


\subsection{Proposition 2: Social Entrepreneurship and Business Partnership}

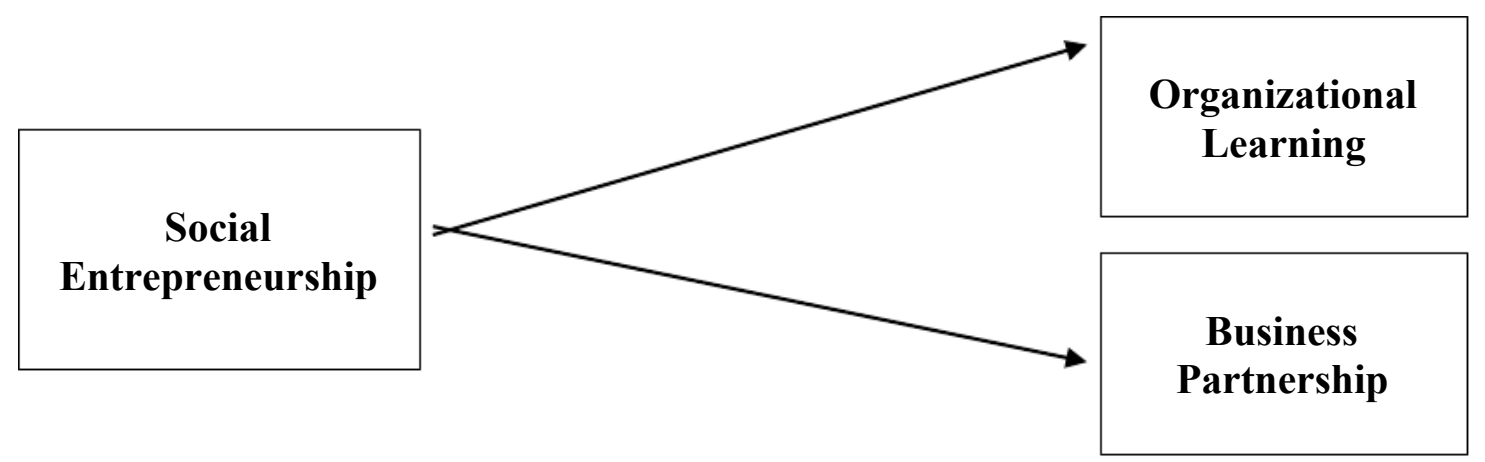

Figure 1 Conceptual Model of the Study

\section{FINDING AND DISCUSSION}

Table 1

\begin{tabular}{|c|c|c|c|c|c|c|c|c|c|}
\hline \multirow[t]{2}{*}{ Variable } & \multicolumn{3}{|c|}{ Loading } & \multicolumn{3}{|c|}{ Weight } & \multicolumn{3}{|c|}{ SMC } \\
\hline & Estimate & SE & \begin{tabular}{|l|l} 
CR & \\
\end{tabular} & Estimate & SE & $\mathbf{C R}$ & Estimate & SE & $\mathbf{C R}$ \\
\hline \begin{tabular}{|c|} 
Social \\
Extrepreneurship (X1)
\end{tabular} & \multicolumn{9}{|c|}{$\mathrm{AVE}=\mathbf{0 , 5 9 5}, \mathrm{Alpha}=\mathbf{0 , 7 7 0}$} \\
\hline $\mathrm{X} 1,1$ & 0,737 & 0,043 & 17,18 & $0,270 \quad 0$ & 0,035 & 7,69 & 0,543 & 0,063 & 8,62 \\
\hline $\mathrm{X} 1,2$ & 0,807 & 0,033 & 24,66 & 0,357 & 0,027 & 13,48 & 0,651 & 0,052 & 12,54 \\
\hline $\mathrm{X} 1,3$ & 0,783 & 0,035 & 22,15 & 0,320 & 0,026 & 12,21 & 0,614 & 0,055 & 11,19 \\
\hline $\mathrm{X} 1,4$ & 0,756 & 0,038 & 19,92 & 0,347 & 0,028 & 12,3 & 0,571 & 0,057 & 10,03 \\
\hline $\begin{array}{l}\text { Organizational } \\
\text { Learning }\end{array}$ & \multicolumn{9}{|c|}{$\mathrm{AVE}=0,568$, Alpha $=0,741$} \\
\hline $\mathrm{Y} 1,1$ & 0,844 & 0,024 & 34,66 & 0,350 & 0,037 & 9,42 & 0,712 & 0,041 & 17,34 \\
\hline $\mathrm{Y} 1,2$ & 0,766 & 0,045 & 17,1 & 0,326 & 0,030 & 10,97 & 0,587 & 0,067 & 8,78 \\
\hline $\mathrm{Y} 1,3$ & 0,750 & 0,043 & 17,31 & 0,302 & 0,027 & 11,11 & 0,562 & 0,064 & 8,75 \\
\hline $\mathrm{Y} 1,4$ & 0,643 & 0,065 & 9,87 & 0,356 & 0,033 & 10,72 & 0,413 & 0,083 & 4,99 \\
\hline Business Partnership & \multicolumn{9}{|c|}{$\mathrm{AVE}=0,629$, Alpha $=0,791$} \\
\hline $\mathrm{Y} 2,1$ & 0,819 & 0,033 & 24,46 & $0,288 \quad 0$ & 0,026 & 10,98 & 0,671 & 0,054 & 12,36 \\
\hline $\mathrm{Y} 2,2$ & 0,814 & 0,028 & 28,84 & 0,334 & 0,030 & 11,29 & 0,663 & 0,046 & 14,48 \\
\hline $\mathrm{Y} 2,3$ & 0,834 & 0,031 & 26,77 & 0,368 & 0,023 & 16,07 & 0,695 & 0,051 & 13,58 \\
\hline $\mathrm{Y} 2,4$ & 0,699 & 0,055 & 12,77 & 0,264 & 0,024 & 10,9 & 0,489 & 0,074 & 6,63 \\
\hline
\end{tabular}

Known variables of Social Entrepreneurship (X1) have a positive influence on Organizational Learning (Y1), meaning that the higher the Social Entrepreneurship (X1), the result will be to elevate the Organizational Learning variable (Y1), where the Path coefficient obtained is 0.652 with a $C R$ value of 11.52 . Because the $C R$ value is greater than the critical value (11.52> 1.96), the statistical hypothesis states that $\mathrm{H} 0$ is rejected, meaning that the variable Social Entrepreneurship (X1) has a Significant influence on the Organizational Learning variable (Y1). 
It is known that the variable Social Entrepreneurship (X1) has a positive effect on Partnership (Y2), meaning that the higher the Social Entrepreneurship (X1) will consequently elevate the Partnership variable (Y2), where the Path coefficient obtained is 0.275 with a CR value of 2,2 . Because the $C R$ value is greater than the critical value $(2.2>1.96)$, the statistical hypothesis states that $\mathrm{H} 0$ is rejected, meaning that the variable Social Entrepreneurship (X1) has a Significant influence on the Partnership variable (Y2).

\section{CONCLUSIONS}

Hypothesis 1 suspects that the variable Social Entrepreneurship (X1) has a significant positive effect on the variable Organizational Learning (Y1). Statistical test results show that there is a significant influence between the variables Social Entrepreneurship on Organizational Learning. A variety of previous studies support these findings, where the arguments most widely proposed because of training and development as a social entrepreneurial commitment proved to have a strong influence on increasing employee self-awareness of the performance achieved. Self-awareness can strengthen organizational learning management. 2. Hypothesis 2 suspects that the variable Social Entrepreneurship (X1) has a significant positive effect on the Partnership variable (Y2). The results of statistical tests show that there is a significant influence between the variables Social Entrepreneurship on Partnerships. A variety of previous studies support these findings, where the arguments most widely proposed because the distribution of corporate social responsibility programs can trigger partnerships between companies and communities. In the case of MSMEs, these activities are usually carried out on the awareness of the owner of the company of the importance of sharing knowledge with fellow MSMEs. In such a context, there is a tendency that fellow MSMEs will form a series of partnership networks.

\section{SUGGESTION}

Based on the results of the analysis of the discussion, the suggestions of this study are as follows: This study found that the application of the concept of social entrepreneurship in the case of MSMEs proved to have implications on several variables of competition and strategic management, both for organizational learning, partnerships, competitiveness, and business performance. The relationship between endogenous and exogenous variables is also positive, which indicates that all of these variables work in harmony and have mutual implications. Therefore, the strategy for developing MSMEs in the future must pay attention to the principles of social entrepreneurship, which are expected to have an impact on optimizing organizational learning, partnership strategies, competitive advantage, and improving business performance.

\section{REFERENCES}

[1] Austin, J., Stevenson, H.,\& Wei-Skillern, J, Social Entrepreneurship and Commercial Entrepreneurship: Same, Different, or Both? Working Paper Series Harvard Business School (04-029), 2003

[2] Azim, M.D.S., Abdullah, H.H., Gorondutse, A.H, Competitive Strategy and Firm Performance: A Review of Literature. International Journal of Business and Tecchnopreneurship7 (1), 2017, pp 87-92.

[3] Barney, J. B., \& Wright, P. M, On Becoming a Strategic Partner : The Role of Human Resource in Gaining Competitive Advantage. Human Resources Management, 37(1), 1998, pp 31-46. 
[4] Bauer, M., Chytilova, J.,\&Morduch, J, Behavioral Foundations of Microcredit: Experimental and Survey Evidence from Rural India. American Economic Review 102(2), 2012, pp 1118-1139.

[5] Beaudreau, B.C, A Humanistic Theory of Economic Behavior. The Journal of SocioEconomics 41, 2012, pp 222-234.

[6] Bongo, I., Arena, M., Azzone, G., \& Calderini, M, Indicators and Metrics for Social Business: A Review of Current Approaches. Journal of Social Enterpreneurship 7 (1), 2016, pp 1-24.

[7] Bornstein, D, How to change the world: Social Entrepreneurs and the Power of New Ideas. Oxford University Press: USA, 2007

[8] Boyd, B. K., Gove, S.,\& Hitt, M. A, Consequences of Measurement Problems in Strategic Management Research: The Case of Amihud and Lev. Strategic Management Journal 26(4), 2005, pp 367-375.

[9] Defourny, J.,\& Nyssens, M, Social enterprise in Europe: recent trends and developments. Social enterprise journal 4(3), 2008, pp 202-228.

[10] Denison, Daniel R, Corporate Culture and Organizational Effectiveness.Wiley Series on Organizational Assessment and Change. Oxford, England, 1990

[11] Dess, G.G., Lumpkin, G.T,\& Taylor, M, Strategic Management: Text and Cases. McGraw-Hill Higher Education: New York, 2004

[12] Dobele, L.,\& Pietere, A, Competitiveness of Social Entrepreneurship in Latvia. Regional Formation and Development Studies 17(3), 2015, pp 40-50.

[13] Doherty, B., Haugh, H.,\& Lyon, F, Social Enterprises as Hybrid Organizations: A Review and Research Agenda. International Journal of Management Reviews 4 (1), 2014, pp 450461.

[14] Godói-de-Sousa, E., \& Júnior, V.M.V, Social Enterprises in Brazil: Socially Produced Knowledge Versus Social Innovation. Journal of Technology Management \& Innovation5, 2013, pp 166-176.

[15] Dr P V Raveendra, Padmalini Singh and Arun Kumar DC, Social Entrepreneurship and CRM: Linking Through Common Factors, International Journal of Mechanical Engineering and Technology, 9(4), 2018, pp. 733-740

[16] Goyal, S.K.,\& Giri, B.C, Recent Trends in Modelling of Deteriorating Inventory. European Journal of Operational Research 134 (8), 2001, pp 1-16.

[17] Grassl, W, Business Models of Social Enterprise: A Design Approach to Hibridity. ACRN Journal of Entrepreneurship Perspective 1 (1), 2012, pp 37-60.

[18] Hashim, N.A.B., Raza, S.,\& Minai, M.S, Relationship between Entrepreneurshiial Competencies And Small form Performance: Are Dynamic Capabilities the Missing Link?. Academy of Strategic Management Journal7 (2), 2018, pp 1-10.

[19] Dr. Sanjeev Kumar, Sanchita Raghav, Apoorva Raj, Ankit Tiwari and Mohan Gautam, Social Innovation and Social Entrepreneurship - An Elucidation for the Problems of Modern Society. International Journal of Management, 8(1), 2017, pp. 212-217

[20] Hobday, M, The electronics industries of the Asia-Pacific: Exploring International Production Networks for Economic Development. Asian-Pacific Economic literature.15 (1), 2001, pp 13-29.

[21] Huang, Y. T, Learning from Cooperative Inter-Organizational Relationships: The Case of International Joint Venture. Journal of Business \& Industrial Marketing 25(6), 2010, pp 454-467. 
[22] Indrawati, S, SME's Product Investment Priority and Selection Based on Local Competencies. Procedia Economics and Finance4 (4), 2012, pp 59-67.

[23] Andriyansah, Femilia Zahra Student Awareness towards Social Entrepreneurship: A Qualitative Study. International Journal of Civil Engineering and Technology, 8(6), 2017, pp. 457-464.

[24] Jennings, P.D., Greenwood, R., Lounsbury, M.D., Suddaby, R, Institutions, Entrepreneurs, and Communities: A Special Issue on Entrepreneurship. Journal of Business Venturing.28, 2013, pp 1-9.

[25] Jones, T. M, Shareholder suits: Good News and Bad News for Corporate Executives. California Management Rev23, 1981, pp 77-86.

[26] Lewis, W.G., Pun, K.F., and Lalla, T.R.M, Exploring Soft Versus Hard Factors for TQM Implementation in Small and Mediumsized Enterprises, International Journal of Productivity and Performance Management, 55(7), 2006, pp 539-554.

[27] M. Malarkodi and Dr. Saifil Ali,Women Social Entrepreneurship and its Impact on Entrepreneurial Performance. International Journal of Management, 9 (1), 2018, pp. 10 15

[28] Li, S., Ragu-Nathan,B., Ragu-Nathan, T.S., \& Subba Rao, S, The Impact of Supply Chain Management Practise on Competitive Advantage and Organizational PerformanceOmega34(1), 2006, pp $107-124$

[29] MacKinnon, D., Cumbers, A., \& Chapman, K, Learning, Innovation and Regional Development: A Critical Appraisal of Recent Debates. Progress in Human Geography 26, 2002, pp 293-311.

[30] Mainsah, E., Heuer, S., Kalra, A., \& Zhang, Q, Grameen Bank: Taking Capitalism to the Poor. Columbia Business School: New York, 2004

[31] Rastislav, R., \& Silvia, L, Strategic Management of Business Performance Based on Innovations and Information Support in Specific Conditions of Slovakia. Journal of Competitiveness7 (1), 2015, pp 3-21.

[32] Prof. T A Venlatalachalam, Dr. G. Sivaramakrishnan, Social Entrepreneurship in Indian Scenario, International Journal of Management, 2 (1), 2011, pp. 58-60

[33] McQuaid, R. W, The Theory of Partnership: Why Have Partnerships? Routledge Advances in Management and Business Studies 19, 2000, pp 9-35.

[34] Mercader, V, Influence of Social Enterpreneurship in Organization, Family, and Society: Causes and Solutions for Success. American Journal of Management 17 (2), 2017, pp 6577.

[35] Mohtar, H.L; \& Mohtar, S. 2015. Social Enterpreneurship: a Different Perspective. International Academic Research Journal of Business and Technology1 (1), 2015, pp 915 . 